\title{
On Becoming a Non-Jewish Holocaust Writer: Yann Martel's Beatrice and Virgil
}

\author{
Rachel F. Brenner
}

check for

updates

Citation: Brenner, Rachel F.. 2021 On Becoming a Non-Jewish Holocaust Writer: Yann Martel's Beatrice and Virgil. Humanities 10: 12 https://doi.org/10.3390/h10010012

Received: 22 September 2020 Accepted: 28 December 2020 Published: 31 December 2020

Publisher's Note: MDPI stays neutral with regard to jurisdictional clai$\mathrm{ms}$ in published maps and institutional affiliations.

Copyright: () 2020 by the author. Licensee MDPI, Basel, Switzerland. This article is an open access article distributed under the terms and conditions of the Creative Commons Attribution (CC BY) license (https:// creativecommons.org/licenses/by/ $4.0 /)$.
Mosse/Weinstein Center for Jewish Studies, University of Wisconsin-Madison, 1354 Van Hise Hall, Madison, WI 53706, USA; brenner@wisc.edu

\begin{abstract}
To appraise Martel's non-Jewish perspective of Holocaust thematic, it is important to assess it in the context of the Jewish relations with the Holocaust. Even though the Jewish claim to the uniqueness of the Holocaust has been disputed since the end of the war especially in Eastern Europe, the Jewish response determined to a large extent the reception of the disaster on the global scene. On a family level, the children of survivors have identified themselves as the legitimate heirs of the unknowable experience of their parents. On a collective level, the decree of Jewish annihilation constructed a Jewish identity that imposed an obligation to keep the Holocaust memory in the consciousness of the world. Martel proposes to supersede the history of the Holocaust with a story which would downplay the Jewish filiation with the Holocaust, elicit an affiliative response to the event of the non-Jewish writer and consequently integrate it into the memory of humanity at large. However, the Holocaust theme of Beatrice and Virgil refuses to assimilate within the general memory of humanity; rather, the consciousness of the event, which pervades the post-Holocaust world, insists on its constant presence. The omnipresence of the Holocaust blurs the distinctions between the filiative (Jewish) and affiliative (non-Jewish) attitudes toward the Jewish tragedy, gripping the writer in its transcendent horror. Disregarding his ethnic or religious origins, the Holocaust takes over the writer's personal life and determines his story.
\end{abstract}

Keywords: Holocaust; memory; identity

\section{Introduction}

Beatrice and Virgil, the long-awaited novel by Yann Martel that followed the author's phenomenally successful, prize-winning Life of Pi, was a colossal commercial and critical failure. Among other narratives, the novel includes a play portraying two stuffed and mounted animals, Beatrice, a donkey, and Virgil, a howler monkey, as victims of the Holocaust, even though they never mention the Holocaust by name. The author of the play is a taxidermist, falsely suspected of being an old Nazi. Reviewers discredited Beatrice and Virgil as a "misconceived and offensive ... disappointing and often perverse novel" (Kukutami 2010), a fiction which made "the whole thing look like an attempt to flesh out a dictionary definition of "postmodernism"” (Hanks 2010), and "an unbearably ... commemorative mind-games and childish euphemisms" (Lasdun 2010).

The scholarly interpretations focus on the allegorical use of taxidermied animals in the context of the Holocaust. They consistently refrain from considering the construction of Beatrice and Virgil, the component which provides a guideline to this interpretation of the novel. Whereas my reading considers the animal aspect of the novel an auxiliary in the process of the author-protagonist's evolution as a Holocaust writer indicated by the genre transition from essay to fiction, the scholars focus on the animals as bona fide protagonists. Danielle Sands examines "the disordered and disturbing associations between the Holocaust and suffering animals" and claims that Martel's "double-ended allegory helps us to reconsider animal suffering" (Sands 2016, pp. 41, 47). Dorina Daniella Vasiloiu argues that the allegorical story of the Holocaust victims as taxidermied animals intends to 
show that "[i]n the same fashion that mounted animals are mere copies of the living ones, experiences [even the Holocaust] lose their initial emotional authenticity once expressed in words" (Vasiloiu 2010, pp. 144-45). Jenni Adams notes the ambiguity of the animal genocide/Jewish genocide allegory and approaches the employment of the animals as "the interplay of the allegorical and nonsensical strategies of representation and reading in Martel's novel" (Adams 2012, pp. 32, 44). K.S.A. Brazier-Tomkins discusses the allegory of the anthropomorphic aspects of animals in Western literature and claims that "Martel has crafted a novel in which nonhuman animals transgress their allotted place as object" (Brazier-Tomkins 2016, p. 6).

Even though she pays little attention to the evolving construction of Beatrice and Virgil, Janis E. Haswell's view of the social function of Martel's novel is closer to my reading of the novel as an unsuccessful attempt to integrate the Holocaust into the collective memory. More specifically, the college professor finds Beatrice and Virgil pedagogically useful for a classroom discussion "of two of the most venerated and vested doctrines in Holocaust studies," namely, the uniqueness of the event of the Holocaust and survivor testimony as the only truthful Holocaust narrative. Haswell seems concerned the post-survivor era threat of the disparaging or distorting views of the horrendous fate of the Jews in the Holocaust and wonders how it will be possible to talk or write about the Holocaust, let alone teach the event authoritatively, once the survivors, the exclusive possessors of Holocaust knowledge, are gone (Haswell 2013, pp. 29, 30).

Haswell's apprehension is well founded; the historical distance from the Holocaust marked by the disappearance of the direct witnesses of the Holocaust has intensified the intentions to downplay or even displace the history of Jewish Holocaust suffering. The latest endeavors by the Polish government not only to construct, but also to legislate a revisionist history of the Holocaust which centers on the Polish heroic rescue of the Jews has extended the question of who owns the Holocaust to the political arena (Subotić 2019, p. 206).

On the cultural arena, however, the disappearance of survivors has not diminished the remarkable interest in the subject of the Holocaust, which has been taken up with remarkable dedication and creativity by the second generation, namely, the descendants of the Holocaust survivors. In view of the predominantly Jewish perspective of the Holocaust, Beatrice and Virgil, despite its flaws, is a work of interest in that it engages with the impact of the Holocaust on the post-Holocaust world from an-other-than-Jewish perspective.

To appraise the position of the non-Jewish writer vis-à-vis the Holocaust, it is first necessary to account for the twofold impact of the Holocaust on the post-Holocaust Jewish mind. On a personal level, the identity of the children of survivors was informed by their role as the sole inheritors and trustees of the parental Holocaust experience. On a communal level, the Holocaust created a collective identity which demanded neither to forget the Jewish catastrophe nor let it be forgotten. The following brief examination of the symbiotic connection of Jews to the Holocaust contextualizes my subsequent reading of Martel's Beatrice and Virgil, whose initial intention is to release the Holocaust from its Jewish signature, create a story which would integrate the event of the Holocaust into the present-day cultural and social Weltanschauung and thus deposit it in collective memory. As the shifting from essay to fiction construction of the novel shows, the story refuses to submit to the author's objective to attenuate its horrific narrative and assimilate it into the world's memory. Rather, it assimilates Henry, the novel's protagonist and an aspiring Holocaust writer, within a world irrevocably imprinted with the Holocaust's haunting presence, which takes over his life and transforms him forever.

\section{The Ungraspable/Inescapable Parental Story}

Whereas the literary responses to the Holocaust by survivors emerge from their own experience and therefore contain the component of the testimony, the Holocaust representations of second-generation writers are bound to fictionalize the event of the Holocaust, which they can only attempt to imagine. Imaginative-literary representations 
of the Holocaust of this kind were vehemently rejected by Elie Wiesel who famously proclaimed that "what is called the literature of the Holocaust does not exist, cannot exist ... A novel about Treblinka is either not a novel or not about Treblinka; a novel about Treblinka is about blasphemy-is blasphemy" (Wiesel 1977, p. 405).

Such objections, which reecho Adorno's famous postulation about the barbarism of poetry after Auschwitz, did not affect the plethora of Holocaust representations by second-generation and even third-generation writers. These imaginative evocations of the destruction of the parental world were attributed to the second-generation writers' emotional needs. By and large, they were assessed as reflections of the indirect traumatic impact of the Holocaust horror on a generation that came into being due to its parents' accidental survival. As Dina Wardi claims, their consciousness of their parents' experience turned the children into "memorial candles" (Wardi 1992); these are "replacement children," who keep the memory of murdered children and other murdered family members alive. Alan Berger's The Children of Job, a comprehensive examination of second-generation American Jewish Holocaust literature, explores this complex psychological situation. The title refers to the second set of ten children granted to biblical Job, to "'replace' those who were killed, although, and this is the point, a lost child is never 'replaced'" (Berger 1997 , p. 5). Those second sets of post-Holocaust children, who cannot share the parental experience, which is neither communicable, nor describable, have inherited what Marianne Hirsch identified as "postmemory," that is, "a powerful and very particular form of memory precisely because its connection to its object or source is mediated not through recollection, but through an imaginative investment and creation" (Hirsch 1997, p. 22). The inaccessible parental experience that has informed the child's psyche can be approximated only through imagination. The psychoanalysts Nicolas Abraham and Maria Torok elucidate the concept of postmemory metaphorically as "the phantoms in the crypt," or "the gaps left within us by secrets of others." Since the Holocaust experience cannot be recaptured, the phantoms cannot be released from the crypt, and the child is forever affected by "the presence of the phantom [that] indicates the effects ... of something that had inflicted ... injury or even catastrophe on the parents" (Abraham and Torok 1994, pp. 171, 175-76). Similarly, Nadine Fresco, who speaks from her own experience as a child of survivors, characterizes survivors' children as "people who had a hand amputated that they never had," and so "One remembers only that one remembers nothing" (Fresco 1984, pp. 419, 421).

Geoffrey Hartman assents that, since all that the second-generation writers have is an "absent memory" of the Holocaust, they must "reconstitute the past from anecdotes rather than direct knowledge" (Hartman 1996, p. 52). Unlike Wiesel, however, Hartman acknowledges the "impressive fiction ... produced by second generation witnesses." He recognizes that while the children "cannot testify with the same historical participation, for it did not happen to them, [t]his does not lessen, however, [their] moral and psychological burden" (Hartman 1996, p. 8).

The issue of the existential burden of the children invokes the question of the ethics of literary imagination in the representation of the Holocaust. As Ellen S. Fine observes, "the silence of their parents and relatives-who transmit the wounds of genocide, and not the memory" compels the children to explore through fiction the unknowable events which have shaped their life narratives even as they confront the dilemma, "do I have the right to speak?" (Fine 1988, pp. 43-44). The impenetrable memory of the event binds them to their parents' experience and at the same time instills a profound sense of guilt and unease.

This array of metaphoric characterizations of their parents' past reflects the emotional lacunae in the children's lives that often seek relief and resolution in art. The literary work of the Israeli writer, Savyon Liebrecht, who was born to survivors in a DP camp in Germany and left with her parents for Israel, where she lives, is a case in point. Liebrecht has published a number of sensitive, critically praised and award-winning collections of short stories that explore the impact of the Holocaust experience of parents-survivors on post-Holocaust family life. In her interviews, Liebrecht confessed "that she knows practically nothing about her parents' past: how many brothers and sisters they had, what 
these siblings were." Significantly, "the wall of silence did not crumble" even on the trip she took with her parents to Poland, where her father, who had survived a number of concentration camps, insisted on reminiscing in Polish, a language she did not understand (Rattok 1998, p. 11). Symbolically, the survivor's choice to tell the story in a foreign language confirms the estrangement of the children.

Art Spiegelman, the son of Auschwitz survivors, who arrived in America by way of Sweden, encountered a similar predicament. In his enormously successful graphic novel Maus, Spiegelman's autobiographical protagonist Art is the listener-recorder of his parents' Holocaust experience. Since his mother's diaries were destroyed after her suicide, the testimony is entirely his father's. But despite hours of recording, Art eventually realizes the futility of his efforts, "I know it is insane, but I somehow wish I had been in Auschwitz with my parents so I could really know what they lived through! I guess it's some kind of guilt about having had an easier life than they did" (Spiegelman 1991, p. 17, emphases in the text). And the guilt is imbued with envy, for Art feels forever estranged from his parents' love for his dead brother, a victim of the Holocaust he was born to replace. Clearly, the role of "a memorial candle," which he was assigned, makes him deeply unhappy.

The haunting presence of the impenetrable past produces a particular family dynamic. Even though distanced from their parents' experience, the "replacement children" are the only legitimate heirs to the Holocaust legacy, which informs their identity and which they feel obligated to preserve and keep alive through their writing.

But the psychological impact of the Holocaust has not been limited to the family life of survivors. The Nazi mission of the complete annihilation of the Jews had a lasting effect on the Jewish collective self-image. The liberation of the concentration camps may have put an end to the physical extermination, but it did not delete the consciousness of the genocidal totality of the Holocaust eternalized in the horrific euphemism of the Final Solution. As the following discussion will show, this consciousness irrevocably affected the Jewish mentality and transformed the Jewish sense of being and acting in the world.

\section{The Final Solution and Jewish Collective Identity}

In her study, The Era of the Witness, Annette Wieviorka argues that Holocaust historians such as Leon Poliakov, Raul Hilberg, Lucy Dawidowicz, and Saul Friedlander (1992) managed to divide the histories of the perpetrators and the victims: "After the war, two historiographical currents emerged, running parallel to each other and keeping two histories of the Holocaust separate from each other. On the one side, there was the history of the 'final solution,' that is, of the Nazi death machine; on the other side, there was a history of the Hurbn, that is the history written from the point of view of the victims" (Wieviorka 2006, p. 89). However, such rigorous scholarly division is found neither in German nor in Jewish post-Holocaust historiography, where these histories cannot be kept apart. The extent to which the Hurbn, a reference to the complete destructions of the Temples, has shaped German post-war social, political, and ethical history-as can be seen, for example, in German reparations to Holocaust victims, Germany's strong ties with Israel, and the innumerable Holocaust memorials in German cities-cannot be examined here. This discussion, which focuses on Jewish post-Holocaust historiography, will examine how the idea of the Hurbn, which forebodes the end of the covenantal identity of the Jewish people, has affected the social, political, and ethical concepts of Jewish post-Holocaust ideology.

The implacable German resolve to eliminate the Jewish people branded all the Jewsgenerational differences notwithstanding - as objects of extermination. This perspective expands the notion of accidental survival from survivor-families to the Jewish people as a whole. In fact, Emil L. Fackenheim, a major philosopher-theologian of the Holocaust, averred that all living Jews were "an accidental remnant," because, as he explained, "except for an accident, we, the Jews of today, would either have been murdered or never been born" (Fackenheim [1982] 1994, pp. 308-9). Bonded by the sentence of death, which extended to all Jews, the accidentally alive Jews are indelibly bound to those who died 
and therefore, "We are obliged to consider ourselves heir to the whole murdered people" (Fackenheim [1982] 1994, p. 308). The accidental survival, therefore, reaffirms the Jews as a people. As Fackenheim famously declared, to remain Jewish after the Holocaust is "'a 614th commandment,' or a 'commanding Voice of Auschwitz,' forbidding the post-Holocaust Jew to give Hitler posthumous victories" (Fackenheim [1982] 1994, p. 299). Thus, the living Jews are inextricably related to the Holocaust victims, and this relationship charges them with the reaffirmation of the covenant.

According to Fackenheim, the additional commandment has been literally embodied by the Jewish State, which both commemorates Jewish powerlessness and represents Jewish empowerment. As the guardian of the memory of the dead and the emblem of national sovereignty, the State signifies the defeat of the Final Solution. This moral triumph bestows upon the Jewish people the mission of Tikkun Olam [mending of the world], which, as Fackenheim sees it, should focus on repairing the Jewish-Gentile relations (Fackenheim [1982] 1994, pp. 303-4). As an accidental remnant and heir to the Holocaust dead, the Jews are morally obligated to engage the Gentiles in changing the world that produced the horror of the Holocaust.

Significant components of Fackhenheim's vision seem to have materialized in Israel and the United States. In Israel, the Holocaust story was epitomized in the catchphrase "never again," which has been used to glorify the State's military might and rationalize its militant politics as a means to prevent another Holocaust. In the United States, Jewish indelible ties to the Holocaust have been confirmed and highlighted by the impact of the Jewish tragedy on American life. Peter Novick's study The Holocaust and Collective Memory discusses the centrality of the Holocaust both in the self-image of American Jews and in the image of the Jews on the American social landscape. As Novick sees it, thanks to its omnipresence in literature, film, theater, and other popular genres, the Holocaust "spread throughout [American] culture at large." And he observes that for "the political center-on some level for all Americans-[the Holocaust] has become a moral reference point." Moreover, the Holocaust Memorial Museum on the Mall in Washington DC has turned into a landmark of tourist pilgrimage, and pedagogy drawn upon the "lessons of the Holocaust" has become an essential component in the American educational system (Novick 1999, pp. 12-13).

The multiple reverberations of the Holocaust in American life attest to the impact of representations of the Holocaust and the literary attempts at Tikkun. Indeed, some of the best Holocaust literature reflects the dedication of Jewish writers to their twofold obligation as guardians of Holocaust memory and menders of the world. Bound to the historical event of the Holocaust by virtue of their Jewish "race," as defined by the Final Solution, these writers ventured with dread and trepidation into the horror of the univers concentrationnaire in search of restoration.

Thus, the preeminent Holocaust novel, See Under: Love authored by the renowned Israeli writer David Grossman begins with the failure of Momik, a second-generation "replacement child," to defeat the imaginary "Nazi Beast" and thus free his parents-survivors from their haunting past. Years later, however, Momik, now the first-person narrator and an aspiring-writer, envisages a Dante-esque scene, whereby his Virgil, a prewar children's literature writer and now a Holocaust survivor, ushers him into the hell of the concentration camp where his wife and child have already been murdered. There, the young writer witnesses how with a story, which masterfully wields the ethics of love, tenderness, and compassion, the old writer gains a moral victory over the Nazi death-camp commander who used to read his stories as a child. The survivor-mentor enjoins the fearful and traumatized young writer to represent the Holocaust horror in a story: "Write about the [dead] baby. Write about his life ... There is no other way. Because you are like me, your life is the story, and for you there is only the story" (Grossman [1986] 1989, p. 297). Since the story both commemorates and transcends death, telling the Holocaust is the only way to mend the world of horror. 
The premise of the redemptive value of telling underlies a critically praised and prizewinning short story "The Shawl" by Cynthia Ozick, a celebrated American Jewish writer. Ozick followed "The Shawl" with "Rosa," published together in a book entitled The Shawl. In the first story, Rosa enters a concentration camp with her baby, Magda, concealed in her shawl. Eventually, the shawl is stolen and the exposed baby is killed by a Nazi guard who throws it against an electrified fence while Rosa is watching, "All at once Magda was swimming through the air. The whole of Magda traveled through loftiness. She looked like a butterfly touching a silver vine" (Ozick 1990, p. 9). It is perhaps possible to claim that the beauty of this poetic image accentuates the horror of the child's execution (Sicher 2005, pp. 104-5). But the subsequent story, "Rosa," leaves off with a message that the hope for mending lies in the act of telling. Mr. Perski, a simple, old American Jew, who intuitively understands Rosa's boundless and timeless grief, responds to her story with a commonsense yet compassionate observation, which restores Rosa to the world of the living, "Sometimes a little forgetting is necessary ... You ain't in a camp. It's finished. Look around, you'll see human beings" (Ozick 1990, p. 58). The capacity to tell the Holocaust experience to another human being enables the victim to gain a perspective which restores meaning to life. As Jews entrusted with the legacy of the Holocaust, Grossman and Ozick feel compelled to recreate the univers concentrationnaire; the obligation to tell enables the writers to perceive the story as a way to mend the world.

The exclusivity of the Jews' relations with the Holocaust complicates the relationship of the non-Jewish writer and the Holocaust. Edward Said's distinction between filial and affiliative relationships helps explain this difference. Filial relationship "[is] held together by natural bonds and natural forms of authority," whereas affiliative relationship represents "transpersonal forms." Thus, "the filiative scheme belongs to the realms of nature and of 'life,' whereas affiliation belongs exclusively to culture and society" (Said 1989, p. 20). Even though the second generation of survivors did not experience the Holocaust, their Holocaust-informed identity as "memory candles" determines their inborn filial responsibility for the parental story. In contrast, the affiliative relationship of non-Jews with the event of the Jewish destruction can be transmitted through education and art. Whereas the Jewish filiation with the Holocaust invokes the mythical origins of the Chosen People that the Germans were determined to erase from human memory, the affiliative perceptions of the event have tried to explain the Holocaust as either a tragic outcome of Western civilization or as its temporary downfall. As the writer-protagonist of Beatrice and Virgil initially believes, his affiliative position will enable him to offer an alternative to the Jewish filial relationship with the Holocaust, which will ascribe the Holocaust to a period of civilizational crisis. Instead, as the following analysis of the novel will show, the distinctions between the filiative and affiliative diminish as the specter of the Holocaust exposes him to the irredeemable stigma of mass murder which contaminates the world at large.

\section{The Affiliative Conceptualization of the Holocaust}

Non-Jewish Holocaust writers have generally been both conscious of and self-conscious about their trespassing into the Jewish filial domain. As Sue Vice observes in her study Holocaust Fiction, the Holocaust literature of non-Jewish authors has been received with suspicion. "It is significant that on the whole fewer unsympathetic questions are raised about those with the 'right' to fictionalize the subject because of their second-generation or Jewish identity ... than those who do not own such a right" (Vice 2000, p. 4). To pre-empt mistrust, authors such as Martin Amis and William Styron went so far as to claim this "right" on account of having Jewish children (Vice 2000, p. 3), while the focus on Christian protagonists in Thomas Keneally's Schindler's List and Styron's Sophie's Choice allowed them to bypass the Jewish death-camp experience. The conspicuous presence of extratextual documentation in the Holocaust fiction, namely the insistence on historical sources, indicates the non-Jewish authors' need to affirm the authentic roots of their fiction (Vice 2000, pp. 11, $38,114,122,131)$. These attempts to proclaim their identification with the tragedy of the Holocaust are not by any means outdated or misplaced. Suffice it to mention the post-1990s 
concept of the "double genocide," which claims that two genocides (the Holocaust and the Communist terror) of equal severity occurred in the Soviet/German/Soviet occupied Eastern Europe (Finkel 2010, pp. 51-70; Dirk 2012, pp. 215-38). At the same time, the arguments that Polish and German suffering and losses in WWII surpassed those of the Jewish Holocaust have circulated since the end of the war in an effort to diminish, even deny the severity of the Jewish destruction. By seeking filial connection to the Holocaust, the non-Jewish authors sought to align with the Jewish Holocaust story while fortifying the legitimacy of their Holocaust writing with historical evidence.

As the following discussion of Martel's position demonstrates, the above distinctions between the Jewish and non-Jewish literary representations of the Holocaust are very much on his mind, as he passionately argues the legitimacy of his differing view of the Holocaust representation. In an interview entitled "Yann Martel: 'Jewish People Don't Own the Holocaust,'" Martel rejects the use of history as an evidence of the authenticity of the Holocaust novel (Moss 2010). In fact, the ars poetica that the narrator of Beatrice and Virgil expounds in the essay part of the book repudiates the focus on history in Holocaust fiction. The narrator, whose omniscience is limited to the stream of consciousness of the protagonist-writer Henry (whose story replicates Martel's own life narrative), tells that while researching his Holocaust novel, he "had noticed ... how little actual fiction there was about the Holocaust. The take on the event was nearly always historical, factual, documentary, anecdotal, testimonial, literal ... That terrifying event was overwhelmingly represented by a single school: historical realism" (Martel [2010] 2011, p. 15).

While defending his novel at a lunch with his editors and publisher, Henry elaborates, "My book is about a new choice of stories. With a historical event, we not only have to bear witness, that is, tell what happened and address the needs of the ghosts. We also have to interpret and conclude, so that the needs of people today, the children of the ghosts, can be addressed. In addition to the knowledge of history, we need the understanding of art. Stories identify, unify, give meaning to. [A] story is life that makes sense" (Martel [2010] 2011, p. 15, emphasis in the text). Clearly, Henry is aware of Jewish Holocaust representations. But while his Jewish counterparts prioritize bearing witness to the "ghosts," whose story refuses closure, Henry prioritizes affiliative ties with contemporary readers, who expect a conclusive interpretation of the event. To accomplish it, "the unwieldy encumbrance of history [should be] reduced and packed into a suitcase. Art as suitcase, light, portable, essential-was such treatment not possible, indeed, was it not necessary, with the greatest tragedy of Europe's Jews?" (Martel [2010] 2011, p. 11). Henry finalizes his credo, "If history does not become story, it dies to everyone except the historian. Art is the suitcase of history carrying the essentials. Art is the life buoy of history. Art is seed, art is memory, art is vaccine." (Martel [2010] 2011, p. 16). For Henry, rather than history informing the Holocaust story, the event of the Holocaust is tailored to the story. Like the size of a suitcase, which determines its capacity, the story adjusts history to its artistic vision. Socially acceptable and culturally engaging, the Holocaust story will establish affiliative relationships with readers who will thus consign it to collective memory.

The figure of speech "art is vaccine" indicates that art not only saves history from oblivion, but also disarms its dangerous elements, thereby immunizing readers against unpleasantness and unease. As Henry sees it, art does not promote social reform, nor does it question the conformist modus vivendi. In fact, we learn that Henry's concept of risk-free art has already proved very successful in his previous literary experience-a clear allusion to Martel's Life of Pi. The opening pages of Beatrice and Virgil introduce Henry as a placid, agreeable individual, who despite his success "continued to live what was essentially a normal, anonymous life" (Martel [2010] 2011, p. 3). His first book, which he wrote because "there was a hole in him that needed filling, a question that needed answering, a patch of canvas that needed painting" fulfilled those needs and did the same for his readers, who "told him that his book had filled a hole in them, had answered the question, had brought colour to their lives." The book established an affiliative synchrony which both writer and readers find comforting, satisfying, and pleasing. 
Henry intends to repeat this gratifying experience with the gimmick of a flip book. It consists of an essay and a novel, which "are attached to a common spine upside down and back-to-back to each other." There is not exit out of the flip book, because "a head-totails flip of the conjoined book will bring you on to its fraternal twin" (Martel [2010] 2011, p. 6). The essayistic and the fictional parts complement each other, giving the author full control over how much Holocaust history is presented, allowing him to leave present-day readers with "light, portable, and essential" knowledge of the Holocaust.

Henry's argument fails to prevail over the professional and commercial objections of his lunch companions. Henry, who believes that life is fundamentally pleasant and that people are inherently good and well-meaning, is incapable of dealing with the rejection of his book and decides to "let go" of his Holocaust project. While it is true that the question of his non-Jewish ancestry was not mentioned at the lunch, it clearly weighs on his mind when he struggles with the defeat of his literary vision; thus, he explains his decision to abandon the Holocaust theme by implicitly recognizing the primacy of the Jewish filiative relations with the Holocaust. He rationalizes that he "wasn't even Jewish," and that since "the matter of the Holocaust was settled" by "Primo Levi and Anne Frank, and all the others ... for all time," there was no reason why even the Jews would care "to have $a$ stranger ... gore their beautiful day with talk of genocide." (Martel [2010] 2011, p. 19, my emphases). Subsequently, he moves with his wife to an unspecified European city where he distracts himself with amateurish cultural activities reaffirming his faith in the continuing humanity's progress despite the Holocaust. He practices the clarinet, works on his proficiency in Spanish, joins a progressive non-professional theater group, and acquires a dog and a cat, whom he names Erasmus and Mendelssohn after the great Christian and Jewish humanists. And so, while awaiting the birth of his first child, Theo, Henry intends to settle into a pleasant existence of leisure.

The problem is that the Holocaust will not let Henry go. In this European city, which, like all European cities, witnessed the liquidation of its Jewish population, the Holocaust invades Henry's reality, making him see "everything in the Holocaust, not only camp victims, but also capitalists and many others, perhaps even clowns" (Martel [2010] 2011, p. 116). The omnipresence of the Holocaust takes the form of an old gruff man, a taxidermist also named Henry, who has written a Holocaust play. This imperious individual, who functions as Henry's alter ego, penetrates Henry's existence and systematically demolishes Henry's Weltanschauung. He dismisses Henry's idea of art as a suitcase, disregards his promise not to bear witness, defies his reductive view of history, and destroys forever his trusting disposition. Most significantly, he exposes the art of the Holocaust as a violent and transformative force.

The omniscient narrator records Henry's losing battle with his alter ego's obsessive preoccupation with the Holocaust's legacy of murder and suffering. Despite his wife's disapproval and the neighborhood's open hostility and unfounded suspicion of the taxidermist as a Nazi, Henry's relationship with the other Henry drives him toward a consciousness that refuses to adjust the perception of the Holocaust to fit the liberal, progressive world picture, which strives to disengage from the past. But it also refuses to limit the signification of the Holocaust to the Jewish tragedy. Henry's eventual takeover of the authorship of the taxidermist's play signals a traumatic transformation of his mind and heart: he realizes that the signification of the Holocaust transcended the filiative and affiliative distinctions between Jews and non-Jews imprinting the world with the indelible consciousness of committed murder.

\section{Beyond Filiation and Affiliation with the Holocaust}

The highly problematic and awkward animal allegory of the play within the novel seems to be tuning in with the above quoted critics who focused on the abuse of the animal world. At the same time, however, the discourse of taxidermy as confluence of history and art offers an important insight in the world marked by its history of murder. 
Unlike Henry's initial reductionist view of history, his alter ego the taxidermist sees the art of taxidermy as a historical study, "What I am actually doing is extracting and refining memory from death. I am no different from a historian, who parses through the material evidence of the past in an attempt to reconstruct it and then understand it. Every animal I have mounted has been an interpretation of the past. I am a historian dealing with an animal past" (Martel [2010] 2011, pp. 95-97). The taxidermist does not aim at a documentation of the past; his intent is to preserve the memory of what was lost by way of a "theatrical" illusion-a reenactment of the past. The need to keep the memory alive requires a deep knowledge of the past, in that case, the animal's body and its environment, to create a theatrical imitation that makes believe that the "the liveliness of the animal denies death ... (Martel [2010] 2011, p. 93). In other words, as the taxidermist sees it, history is not by any means recorded factual findings about the disappeared past; rather, history is an artistic reconstruction of the past that does not exist anymore. In this sense, history emerges from the art which makes us see what was lost. In this sense, the taxidermist-historian invokes and preserves the beauty that was irrevocably destroyed.

The beautiful trompe l'oeil of Beatrice and Virgil, which makes them appear to be alive, contrasts with the torture and death to which their post-mortem taxidermied condition attests. Indeed, as the taxidermist explains to Henry, the moral message of his play indicts the "indifference of the many" and the "active hatred of the few" that has "sealed the fate of the animals" in an "irreparable" senseless murder (Martel [2010] 2011, p. 98). The taxidermist's explanation of the beauty of his art as an indictment of the history of persecution and murder which has destroyed this beauty constitutes a further step in the evolution of Henry's understanding the moral value of the aesthetic representation of atrocity.

Even though he is exposed to the mechanics of the taxidermist craft, as represented by a detailed description of the workshop, initially Henry is unable to perceive the tragic meaning of the taxidermied animals' beauty. Entering the showroom, "Henry ... stared wide-eyed. A tingle of excitement passed through him. Now here was a stage full of stories" (Martel [2010] 2011, p. 61). Indeed, a group of taxidermied tigers triggers Henry's imagination. So much so that he is physiologically drawn into the story he invents: it is a story of a hunting scene in which Henry identifies with the escaping cub, a product of his imagination, to the point that he feels how the cub's heart resonates with his own.

In contrast with Henry's aesthetic which makes him produce and also merge with his fiction, the taxidermist's aesthetic is of an observer and preserver of the past. As he tells Henry, "When I work on an animal, I work in the knowledge that nothing I do can alter its life, which is past. What I am actually doing is extracting and refining memory from death. In that, I am not different from a historian, who parses through the material evidence of the past in an attempt to reconstruct it and then understand it" (Martel [2010] 2011, p. 96). The symbolic stage design of the taxidermist's play reaffirms his emphasis on history. The staging of the play on the vertical stripes of a shirt that is "projected not only on the back wall but right across the stage and onto the spectators," and over the "whole theatre" communicates that, as symbolically represented by the shirt, the Holocaust has turned the whole world into a concentration camp. Whereas the reconstructed beauty of the actors, Beatrice and Virgil, invokes the world that was destroyed, the striped shirt symbolizes how the present-day world contaminated by the murder, "The United States of America, the United Clothes of Europe, the Union of African Shoes, the Association of Asian Hats-names are arbitrary. We parcel out the earth, give name to landscapes, draw maps, and then we make ourselves at home" (Martel [2010] 2011, pp. 106-7). But this "parceled earth" which makes us feel comfortable has no past, which has been destroyed: it "has no story. It rests on the fact of murder" (Martel [2010] 2011, p. 167). That is why Virgil and Beatrice, the victims of the murder, who belong to the beautiful world of innocence, will never change. "They remain the same before, during and after" the atrocity, the taxidermist instructs Henry, while "It is we", the dwellers of the symbolic striped shirt, "who have to change" (Martel [2010] 2011, p. 154, emphasis in the text). 
And so, while Henry foregrounds his art of telling, the taxidermist sees his art as a mission "to bear witness" so that the memory of the atrocities will be preserved (Martel [2010] 2011, p. 98). Even as the play is symbolically staged as a universal concentration camp, it does not omit the historical aspects of the disaster. Thus, negative billboards disparaging monkeys who are "cunning," "antisocial," "temperamentally undesirable" (Martel [2010] 2011, pp. 76-77) are displayed, and in the café incident Virgil experiences the news of having been placed in "a new category of non-citizens" that affect him as "the expulsion from Eden" (Martel [2010] 2011, pp. 128-29, emphasis in the text). Furthermore, the subject of the play, an "irreparable abomination," later defined as "the Horrors" (Martel [2010] 2011, pp. 135-36) reenforces the historical reality of the staged events.

In fact, the taxidermist's play follows the tradition of art which presaged the collapse of humanistic values. The taxidermist's play draws upon the dark vision of humanity in the prescient story by Gustave Flaubert, "The Legend of Saint Julian Hospitator," which replaces the sanctity of life with the glorification of mass murder. Based on the legend of Saint Julian, it tells of the saint's sadistic slaughter of innumerable animals, scores of human beings, and even his parents. In a complete negation of Christian teachings, Julian attains salvation and sainthood without even acknowledging, let alone atoning for, the murders that he had committed. Thus, Flaubert envisages the abolition of the commandment "Thou Shalt Not Murder," as indiscriminate slaughter of all living beings, animals and humans alike. In a horrifying and at the same time ironic turn, the foundational Story of Creation transforms into a story of destruction when "[s]ometimes in a dream [Julian] would see himself as our father Adam in the Garden of Eden among all the beasts: by stretching his arm, he would make them die: or ... he would throw javelins at them, never missing his mark; more animals would come; the slaughter would go on" (Martel [2010] 2011, pp. 39-40).

In contrast, Henry professes faith in the 18th-century ideals of religious tolerance and ethics. He takes part in a performance of Nathan the Wise, the play by Gotthold Lessing, which promotes the Enlightenment idea of a moral and just God, whose teachings of love and compassion are shared by the three monotheistic religions. Yet, as the end of Henry's pets' amicable friendship signals, Lessing's famous friendship with Moses Mendelssohn, the father of the Jewish Enlightenment, who inspired his play, did not fulfil its promise of peaceful fellowship. Erasmus the dog contracts rabies and attacks viciously Mendelssohn the cat. This act of violence, which destroys both animals, symbolizes the transformation of the value of friendship among all children of God into hatred, cruelty, and death.

The search for God in the play Beatrice and Virgil exposes the collapse of Christian humanism that Henry refuses to acknowledge. Here Beatrice and Virgil are discussing the reconstruction of their relationships with God:

Beatrice: Have your godless days. Why don't you say Mondays, Tuesdays and Wednesdays?

Virgil: But there is evil everyday of the week.

Virgil: I can't pray. It must be Tuesday, one of my godless days.

Beatrice: Then let us talk about God again on Friday. Until then, think of this: perhaps God is silent so that he might hear us better (Martel [2010] 2011, pp. 107-8).

The absurd idea of restoring God "part time" refutes Henry's idea of adjusting the history of the Holocaust to the present. The God who listens to human prayers cannot co-exist with the history of Holocaust evil. The post-Holocaust world is godless.

While Henry insists on reenacting the play Nathan the Wise which affirms the ideals of the Enlightenment, the play Beatrice and Virgil affirms that the consciousness of evil that affects the post-Holocaust world is not a matter of choice. In the scene of the play entitled the Sewing Kit, Beatrice and Virgil attempt to restore a semblance of normal life through lists of vocabulary items that would allow them "To remember and yet go on living. To know and yet to be happy. Like living with a cat. Always there ... but not constantly on our mind." But though the kit includes seemingly neutral terms, it ends with "aukitz," 
whose association with "Auschwitz" eliminates an even momentary distance from the Holocaust (Martel [2010] 2011, pp. 137-38). Like the concentration camp represented by the striped shirt transformed the world, the Holocaust infiltrated the vocabulary of the post-Holocaust life.

The encounter with the kit makes Henry begin to realize that history cannot be shaped and reshaped to fit the suitcase of art. The epiphany that the item "68 Nowolipki Street" in the sewing kit alludes to the Oneg Shabbat Archives, the famous historical testimonies of the Warsaw Ghetto compiled by the historian, Emmanuel Ringelblum "emerged so forcefully that it punctured his sleep" (Martel [2010] 2011, p. 169). The history of "irreparable abomination" has infiltrated Henry's subconscious; no longer can he ignore the failure of the Enlightenment. Indeed, the taxidermist affirms the omnipresence of the abomination when he claims that 68 Nowolipki Street is "In a corner of every mind and on plaque of every city" (Martel [2010] 2011, p. 179) and Virgil sees no escape from history in an act of art when he "has the idea for short plays where every word ... would be qualified by sic, because every word, in the light of the Horrors is erroneous" (Martel [2010] 2011, pp. 150-51).

Indeed, the play ends with two horrific testimonies by Beatrice and Virgil. These recollections of Horrors depict a reality so brutal and sadistic that they do not even require the designation sic.: it is clear that they depict the world of Horrors. They not only tell, in horrifying detail, of Beatrice and Virgil's torments and eventual death inflicted by young persecutors, but also of two women and their babies driven to death by drowning by the same young sadists. The youth of both the victims and the victimizers points to a dark future which does not promise redemption. Reechoing Flaubert's story, in which a saint excels as murderer as every living creature has provoked his desire to kill; life itself has become the object of destruction, defenseless in view of the perpetrators' purposeless evil for the sake of evil. The play ends on an appalling scene in which the dead animals, Beatrice and Virgil, play games with a dead man, named Gustav, most probably in commemoration of Gustave Flaubert. These macabre games are just "another way they find of talking about the Horrors" (Martel [2010] 2011, p. 186). While the players are dead, their play with death refuses to die.

As Henry finally learns, becoming a Holocaust writer is not a matter of choice. When he refuses to assume the authorship and therefore the ownership of the play, his alter ego stabs him with "a short, blunt knife ... just below the ribs" (Martel [2010] 2011, p. 191). Then the taxidermist vanishes without a trace in the flames that consume his shop, but not before "Their eyes met. He smiled at Henry. It was a full smile that lit up his face" (Martel [2010] 2011, p. 193). The alter ego/taxidermist has accomplished his mission; the Holocaust has been ineluctably imprinted on Henry's soul and body.

It is perhaps possible to see the stab as a symbolic act of Henry's consecration as a writer of the Holocaust murder. The dramatic episode communicates Henry's transformed approach to the history of the Holocaust. In the aftermath of the final scene with the taxidermist, "the quality of [Henry's] life has changed." The traumatic encounter with Holocaust art, which ended up in an act of violence, made him abandon his naïve faith in the goodness and progress of humankind and "acquire companions that never leave you entirely: Suspicion, Fear, Anxiety, Despair, Joylessness" (Martel [2010] 2011, p. 193). While his voluntary reconstruction of the play, which he names Beatrice and Virgil, communicates Henry's irrevocable relationship with the Holocaust, he also fulfills the taxidermist demand to write "Games for Gustav," which makes him a Holocaust writer in his own right. In "Games for Gustav," he invokes the horrifying "games," or the "choiceless choices" that the Holocaust victims faced, such as choosing which of their children will die (Langer 1982, p. 72). Henry's eventual affirmation of his relationships with the Holocaust victims communicates an understanding of the Holocaust, which includes him as dweller of a world contaminated with murder. In this sense, it is not the artist that determines the Holocaust story, nor is it his filiative or affiliative relation with the event, but rather it is 
the Holocaust story that measures the authenticity of the Holocaust writer by shaping his reality as constant longing for a world which was lost and cannot be recovered:

"Henry regretted not having saved Beatrice and Virgil. He missed them with an ache that made itself felt even years later. It was the same kind of pain he felt when he had to be any length of time away from Theo, a physical hunger for presence" (Martel [2010] 2011, p. 149).

\section{A Brief Conclusion}

Oddly enough, the experience of writing the novel Beatrice and Virgil did not seem to change Martel's views about Holocaust literature. In the "A Conversation with Yann Martel" with Random House Reader's Circle appended to the novel, he reiterates the reductionist idea of art as a suitcase expounded by Henry in the beginning of the novel, as if Henry's transformation, which alienated him from such ideas, did not occur.

A writer has no responsibility for interpreting his work, but the critic, I believe, should follow D.H. Lawrence's wise adage, "Never trust the teller, trust the tale. The proper function of a critic is to save the tale from the artist who created it." Therefore, it seems appropriate to end this essay with an insight from Beatrice and Virgil into the issue of Holocaust representation that, in a way, "saves" the novel from its author's own apparent disengagement from its message. As a non-Jewish writer, Martel's protagonist and alterego Henry cannot ground his ties with the Holocaust in the decree of death that the Final Solution meant to Jewish writers. But while he did not inherit the history of the existential doom of the Jews, the awful sense of Beatrice and Virgil's absence evinces how their fate has robbed him of his moral and cultural self. The title of the play refers to The Divine Comedy, the epitome of European Renaissance literature. But Henry's decision to call his novel Beatrice and Virgil "went to the heart of the encounter" (Martel [2010] 2011, pp. 196-97) with the Holocaust which replaced Enlightenment thought with murder. His portrayal of the murdered animals, who are forever captured in a godless world of the vocabulary of Holocaust evil evinces irrecoverable loss of culture and beauty. The compulsion to experience this loss and mourn it reaffirms the ties of all of us with the Holocaust as a global disaster which forever changed the world.

Funding: This research received no external funding.

Institutional Review Board Statement: Not applicable.

Informed Consent Statement: Not applicable.

Data Availability Statement: Not applicable.

Conflicts of Interest: The author declares no conflict of interest.

\section{References}

Abraham, Nicolas, and Maria Torok. 1994. The Shell and the Kernel: Renewals and Psychoanalysis. Chicago: The University of Chicago Press.

Adams, Jenni. 2012. A Howl and a Black Cat: Allegory, Nonsense, and Ethics in Yann Martel's Beatrice and Virgil. Journal of Literature and Trauma Studies 1: 31-63. [CrossRef]

Berger, Alan L. 1997. Children of Job: American Second-Generation Witness to the Holocaust. New York: State University of New York Press.

Brazier-Tomkins, Kali Shakti Arnelle. 2016. Subject: Animal: Representing the Seeing Animal in Yann Marcel's. Beatrice and Virgil. Studies In Canadian Literature-Etudes En Litterature Canadienne 41: 5-24.

Dirk, Moses Anthony. 2012. The Canadian Museum for Human Rights: The 'Uniqueness of the Holocaust' and the Question of Genocide. Journal of Genocide Research 14: 215-38. [CrossRef]

Fackenheim, Emil L. 1994. To Mend the World: Foundations of Post-Holocaust Jewish Thought, 2nd ed. Bloomington: Indiana University Press. First published 1982.

Fine, Ellen S. 1988. The Absent Memory: The Act of Writing in Post-Holocaust French Literature. In Writing and the Holocaust. Edited by Berel Lang. New York: Holmes \& Meier, pp. 41-57.

Finkel, Evgeny. 2010. In Search of Lost Genocide: Historical Policy and International Politics in Post-1989 Eastern Europe. Global Society 24: 51-70. [CrossRef]

Fresco, Nadine. 1984. Remembering the Unknown. International Review of Psycho- Analysis 11: 417-27. 
Friedlander, Saul. 1992. Probing the Limits of Representation: Nazism and the 'Final Solution. Cambridge: Harvard University Press.

Grossman, David. 1989. See under: Love. Translated by Betsy Rosenberg. New York: Washington Square Press. First published 1986. (In Hebrew)

Hanks, Robert. 2010. Beasts of Burden. The New York Times, April 30.

Hartman, Geoffrey. 1996. The Longest Shadow: In the Aftermath of the Holocaust. New York: Palgrave.

Haswell, Janis E. 2013. Students, Teachers, and the Aftermath of the Horrors: Reflections on Teaching Martel's. Beatrice and Virgil. English Language and Literature Studies 3: 28-47. [CrossRef]

Hirsch, Marianne. 1997. Family Frames: Photography, Narrative and Postmemory. Cambridge: Harvard University Press.

Kukutami, Michico. 2010. From 'Life of Pi' Author, Stuffed-Animal Allegory about the Holocaust. The New York Times, April 12.

Langer, Lawrence. 1982. Versions of Survival: The Holocaust and the Human Spirit. New York: State University of New York Press.

Lasdun, James. 2010. Beatrice and Virgil by Yann Martel. The Guardian, June 4.

Martel, Yann. 2011. Beatrice and Virgil. New York: Spiegel \& Grau Trade Paperback. First published 2010.

Moss, Stephen. 2010. Yann Martel: 'Jewish People Don't Own the Holocaust'. The Guardian, June 22.

Novick, Peter. 1999. The Holocaust and Collective Memory. London: Houghton Mifflin.

Ozick, Cynthia. 1990. The Shawl. New York: Vintage House.

Rattok, Lily. 1998. Introduction. In Savyon Liebrecht, Apples from the Desert: Selected Stories. Translated by Marganit Weinberger-Rotman, Jeffrey M. Green, Barbara Harshav, Gilead Morahg, and Riva Rubin. New York: The Feminist Press at the City University of New York, pp. 9-35.

Said, Edward. 1989. The World, the Text and the Critic. Cambridge: Harvard University Press.

Sands, Danielle. 2016. On Tails and Tales: Animals, Ethics, and Storytelling in Yann Martel's Beatrice and Virgil. Critique: Studies in Contemporary Fiction 57: 41-51. [CrossRef]

Sicher, Efraim. 2005. The Holocaust Novel. New York: Routledge.

Spiegelman, Art. 1991. Maus II. New York: Pantheon Books.

Subotić, Jelena. 2019. Yellow Star, Red Star: Holocaust Remembrance after Communism. Ithaca: Cornell University Press.

Vasiloiu, Dorina Daniella. 2010. Homo Fabula and Dimensions of Story Tellability in Yann Martel's. Life of Pi and Beatrice and Virgil. American, British and Canadian Studies 15: 139-47.

Vice, Sue. 2000. Holocaust Fiction. Oxford: Routledge.

Wardi, Dina. 1992. Memorial Candles: Children of the Holocaust. Translated by Naomi Goldblum. London: Tavistock/Routledge.

Wiesel, Elie. 1977. Art and Culture after the Holocaust. In Auschwitz: Beginning of a New Era? Reflections on the Holocaust. Edited by Eva Fleischner. New York: KTAV, pp. 403-15.

Wieviorka, Anette. 2006. The Era of the Witness. Translated by Jared Stark. Ithaca: Cornell University Press. 